\title{
Studying Service SME Adoption of Mobile Marketing Technology (MMT) via Technology-Organization- Environment Framework
}

\author{
Sunday Chinedu Eze, Landmark University, Nigeria \\ Vera Chinwendu Chinedu-Eze, Michael Okpara University of Agriculture, Nigeria \\ Hart O. Awa, University of Port Harcourt, Nigeria
}

\begin{abstract}
While the acceptance and use of mobile marketing technology (MMT) is playing a significant role in small and medium enterprises (SMEs), few studies have explored how an appropriate framework for understanding the underlying factors that shape MMT adoption in Nigeria can be developed. This is because the majority of practitioners in Nigeria often generalize and extend the findings from the developed economies as if there are no environmental differences. This paper attempts to propose a grounded theory approach for assessing factors within technology-organisation-environment (T-O-E) framework in an attempt to explain and predict small service firms' adoption of MMT. The data collection approach spans unstructured and semi-structured interviews with 26 respondents, and the proposed framework provides an organized way to explore MMT adoption and a foundation for developing a model of MMT adoption in developing countries.
\end{abstract}

\section{KEYWORDS}

Adoption, Grounded Theory, MMT, Nigeria, SMEs, TOE

\subsection{INTRODUCTION}

The relevance of the service sector and of the digital devices, particularly the MMTs, and their concomitant adoption by different categories of enterprises is obsessively on surge (Charoensukmongkol \& Sasatanum, 2017). Report from the National Bureau of Statistics (NBS, 2015) affirmed that the service sector contributes 52.99 percent of the GDP in the first quarter of 2014, which is the largest in Nigeria; and the telecommunications industry accounted for 27.36 percent of it; whereas, agriculture accounted for 19.65 percent. Similarly, Nigeria is the biggest and the most promising mobile telecommunications market in Africa with over 75 million subscribers and market penetration rate of about 61.53 percent; and 76 percent of internet traffic from mobile devices (https://abbakin. com/mobile-marketing-in-nigeria/). From 2014 to 2017, internet usage in Kenya rose from 48 to 53 percent against Nigeria, where it surged from 62 to 65 percent; and in South Africa, it increased from 48 to 65 percent (https://abbakin.com/mobile-marketing-in-nigeria/; Ekakitie-Emonena \& Odanibeh, 2016). Beside the COVID-19 induced movement restriction, scholars (Amirkhanpour et al., 2014; Inegbedion et al., 2019; Ma et al., 2009) suggest that the surge is obvious, because of the affordability 
of mobile devices and other digital marketing applications that provide opportunities for large and small businesses to regularly advance their interactions, and businesses/marketing processes. Scholars (Lamarre et al., 2012; Shankar et al., 2010; Balasubramanian et al., 2002) consider MMTs and other marketing devices most effective and dynamic, because they involve personalized marketing and ubiquitous interactions within the value chain.

The implementation of MMT is vastly turning a vital marketing communication strategy for most organizations (Leppäniemi \& Karjaluoto, 2008; Inegbedan, 2018), given the real-time and cost-effective sharing of contents. In the UK and US, for instance, many consumers are mobile users (Storm et al., 2014); nearly 71 percent of UK consumers buy and sell via mobile applications (Park et al., 2006); and from 2000 to 2008, MMT surged universally to 24 percent, accounting for 4 billion in the last quarter of 2008 (Eze et al., 2019). Similarly, an inquiry shows that global MMT expenditure accounted for 17.96 billion USD and will be multiplied by the end of 2016 (Amirkhanpour et al., 2014). Another study report $90 \%$ of firms are core investors in MMT, and approximately $25 \%$ of the entire marketing budget is linked to MMT (Sultan et al., 2009). Other studies (e.g Earl \& Feeny, 2012) show that SMEs rarely break-even or even make profits if they fail to adopt and implement emerging technology at the right market levels. Hence, the adoption of MMT has become a strategic tool for the survival of both large and small firms (Kim et al., 2008; Harvie, 2010; Eze \& ChineduEze 2018), given that it consistently provides level-playing grounds and promotes interactions with clients and allies even outside physical presence (Eze et al., 2019; Nguyen et al., 2015).

In spite of the growing potentials of MMT in speeding up socio-economic developments amidst COVID-19 and its associated restriction of movements; scholars (Awa et al., 2017a; Eze et al., 2019; Awa, 2018) posit that majority of SMEs are yet to fully harness such potentials, owing to lack of indigenous frameworks that guide successful adoption, safety and security issues, uncertainty of use, issues of corporate culture and business mind-set, technical know-how, inadequate internet facilities and limited finances (Ojeme \& Onuba, 2010; Inegbedion \& Obadiaru 2018). In Nigeria, MMT adoption by SMEs remains sceptical regardless of the onerous encouragement by the government via N-Power, CBN, SMEDAN, Banks and Micro-finance banks, and others. However, studies are necessitated to unveil the key underlying adoption factors owning to the socio-economic criticality of mobile marketing and SMEs, and the dearth of adoption frameworks that may guide decisions. First, the critical mass of extant scholars (Lip-Sam \& Hock-Eam, 2011; Earl \& Feeny, 2012; Inegbedan, 2018) extensively deployed positivist approach to study MMT adoption. Such studies considered MMT adoption as straightforward, and relied broadly on quantitative approach (Williams et al., 2009). Gilmore and Carson (2007) posit that discovering problems associated with SMEs should not only focus on testing theories, but also on in-depth exploration to build theories and get more comprehensive dimensions of small business context.

Second, on accounts of environmental differences; the adoption of MMT and other digital technologies has witnessed obsessive cross-context studies in the developing nations (Eze et al., 2018; Eze et al., 2019; Martin \& Matley, 2001). Such is laudable and provides context-specific factors that underlie the adoption, but a more scholarly and insightful theoretical contribution than just crosscontext inquiries is assumed when such studies are underpinned by the ground-breaking framework of technology-organization-environment (T-O-E). The T-O-E framework is more theoretically and empirically validated than most other adoption frameworks, and provides the socio-economic attributes of any technology against the illusion of accumulated tradition and determinism (Eze et al., 2013; Inegbedion, et al., 2019; Awa et al., 2017a). Research works recognize the overlapping and deterministic nature of some of adoption theories: TRA is attitudinal, TAM undermines the interplay of social and emotional issues, and IDT and TPB overtly underplay the environmental and technological contexts (Awa, 2018) TAM's constructs overlap some of those in IDT; IDT's constructs interfaced with T-O-E's technology and organization; and the presence of environment in T-O-E makes it almost the most robust and populous IS framework for studying all manner of adoption by all manner of firms. 
Therefore, this study complements extant studies on MMT adoption, proposes a home-based roadmap of MMT adoption factors, and analyses the factors using the qualitative research approach. The criticality of this lies on the significance of the informal sector in the socio-economic development, owners' scepticism over adoption and implication of MMT, as well as the seeming dearth of local inquiries that direct knowledge, insights and proactive and/or reactive decisions on adoption of emerging devices. And so, getting to know the underlying factors that shape SMEs' adoption of MMT improves use tendencies, and assists to the design of attacks and counter-attacks on competitors.

\section{LITERATURE REVIEW}

\subsection{Mobile Marketing Technology and SMEs}

Mobile marketing technology is defined as mobile applications or devices engaged by two or several persons mainly for interaction and advertising of products amid businesses and clients (Eze et al., 2019; Eze et al 2019). It also defines the use of mobile advertising for interaction and marketing communication (Shankar \& Balasubramanian, 2009). Implicit is that MMT may substitute virtual marketing; boast SMEs' sales promotions policy; and increase profit margin. Mobile marketing is fast becoming an integral part of marketing strategy primarily, because of its improved infrastructure, direct reach, cheaper devices, and lower data costs. The adoption of MMT is a deliberate socio-economic process with known consequences of efficiency, and ability to build competitive advantage (Awa $e t$ al., 2015; Orlikowski, 1993; Awa \& Ukoha, 2016). With the COVID-19 pandemic and programmes to contain its global spread, the world turns flatter and even a more level playing ground by digital devices; forcing the operations of enterprises of all sizes to key into the concomitant potentials. Frankly, the COVID-19 induced-lock-down is reshaping the global socio-economic activities; thus, causing SMEs to seek IT-innovations that assuage the effect of their barriers, strengthen non-physical collaboration and communications within the value chain, and improve customer satisfaction.

However, SMEs are often defined in cross-country context to reflect such measurement metrics as capital, annual turnover, fixed assets, employment figures, and industry type (Awa \& Ojiabo, 2016). The US Small Business Administration (USSBA) and the Organization for Economic Co-operation Development (OECD), suggest that SMEs employ less than 500 persons (OECD, 2000). In the UK, between 1 and 250 (Tilley \& Tonge, 2003); and in Nigeria, SMEs are categorized into three: micro - 1-10 employees, small 11 - 50 employees, and medium 51 - 250 employees (SMEDAN, 2005). The Japanese small is beautiful (Awa et al. 2015) and the world is flat (Friedman, 2005) suggest encouraging the informal sector or SMEs, because they are the bedrock for industrialization and/or the drivers of socio-economic infrastructure in the forms of local capital formation, and innovation (Awa, 2018; Ramdani et al., 2009). In Nigeria, Ihua (2009) estimated that about 97 percent of enterprises are SMEs, and they employ about 50 percent of the working population, and contribute about same 50 percent to the country's industrial outputs. Scholars (Ongori \& Migiro, 2010) posit that the strategic position occupied by SMEs in socio-economic development, as well as their obsessed drawbacks informed the rapid and continual assistance from government and her agencies to improve their operation through the adoption of modern IT technologies. However, SMEs still face with challenges of adopting the right MMT. Amongst others, scholars investigated the adoption of mobile marketing devices using intentional and behavioural based theories (see Ajzen \& Fishbein, 1980; Davis, 1989; Rogers, 1995; Porter, 1985; Premkumar, 2003; Adams et al., 1992; Pavlou \& Fygenson, 2006). Although these and other theories and models make vital scholarly contributions to the adoption literature, they were rarely designed with SMEs' characteristics in mind and as such, they overlooked some vial aspect of SMEs.

Further these underpinning theories and models assume traditional, perfect information, and illusion of accumulated traditions that predict individual-level adoption (Oliveira \& Martins, 2011). Awa et al. (2017a) are of the opinion that perfect information are rare, and so informed adoption decisions do not follow the dictates of deterministic and non-social interactions. Integrating IDT and 
other traditional frameworks, T-O-E represents an alternative framework that sufficiently explains SMEs' adoption strategy, because it is less attitudinal and utilitarian, and recognizes the social and psychological parameters - individuals rather technology determine adoption.

\subsection{Theoretical Underpinning}

T-O-E framework underpins this work, because it is a more integrated and more holistic framework that earns robust theoretical and empirical validation, and offers updated information that meets the contemporary demand for more social interaction. In attempt to explain the intra-and-inter firm adoption better than IDT and other traditional frameworks, the framework integrates the environmental context (Oliveira \& Martins, 2011). It has more insightful theoretical lenses (Eze et al., 2018), which assist to unravel broad influence on MMT adoption, given that it spans factors of technology, organization and environment, and provides significant methodical tool for examining the adoption of wide-ranging emerging technological innovations (Oliveira \& Martins, 2011). Further, the elements of T-O-E form the bases for exploring all-encompassing factors that shape MMT adoption. The analytical framework is shown Figure.

The framework has three dimensions; first, technology context, which outlines the features of technologies that are within and external to the organization which are suitable for improving efficiency and productivity; it include those the organization is currently using, those available in the market but yet to be tested, improved or tried by the organization (Gupta et al., 2013, Eze et al., 2014; Eze et al., 2018). According to Baker, (2012) cognate knowledge acquired internally or externally by the firm encourages adoption, provided positive changes are guaranteed by such decision. Technology context relates to those internal factors which firms consider critical to the anticipated performance of an innovation. Studies (Alshamaila et al., 2013; Eze et al., 2019; Eze et al., 2012; Eze et al., 2020; To \& Ngai, 2006) investigated factors related to technology such as compatibility, perceived affordability and relative advantages and argue that technology dimension provide guide to so many studies, and are relevant in exploring MMT adoption.

Second, organization-context relates to firm resources and firm characteristics such as the size of the firm, its scope of operations, employee capability, management support, intra-firm communication (Baker 2002). Maduku (2016) found that for innovation adoption to flourish, top management must communicate its role within the organization over-all policy, stress its significance on creativeness, newness and cooperation in the organization. This is determined depending on the community engagement with the various stakeholders within and outside the organization. The manner in which a firm engage with employees in the organisation shows how the management of the organisation relate with other departments or units in the organisation. A community that encourages the initiatives of the rank and files with the organisation has less stress making adoption decisions (Awa et al., 2015). Although it has been argued that perceived employee acceptance and top management support are core adoption factors Studies (Gutierrez et al., 2015), many of these studies focused on innovation adoption, a large number of them failed to look at factors that influence the adoption of MMT in Nigeria

Third, environmental context deals with factors that influence the adoption of MMT (Andries \& Debackere, 2006). This extends to location of the firm, structure of the firm, regulatory structures, customer and competitive dynamics, trading partners' readiness, economic trends, availability of IT vendors/consultants, and globalization (Tornatzky \& Fleischer, 1990; Mehrtens et al., 2001). Further knowledge on the factors within the environment-context has been examined across studies (Eze $e t$ al., 2018, Eze et al., 2019; Kuan \& Chau, 2001). Firms build competitive edge when they carefully examine the environmental factors that shape adoption decision of MMT. 


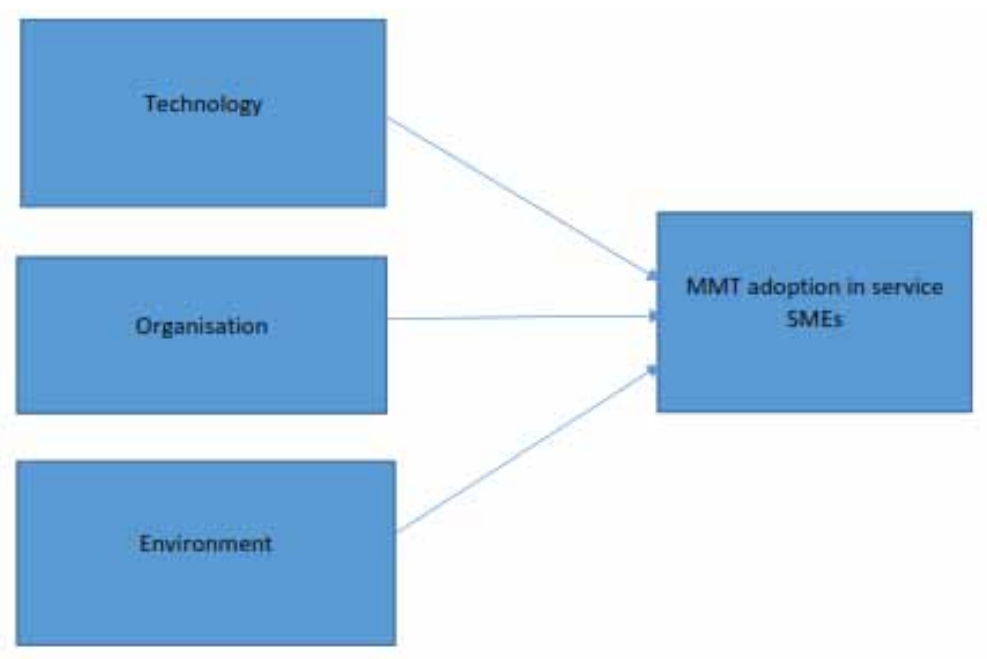

\subsection{METHODOLOGY}

\subsection{Process and Sampling}

This study was conducted using qualitative method to examine factors that shape MMT adoption in order to propose a model of MMT adoption in service SMEs in Nigeria. The research started by reviewing existing literatures in the area of MMT which eventually facilitated the understanding of the various areas of the study that previous studies have investigated and to know the future areas to be explored. Because of the qualitative nature of the study the researchers identified and draw from the categories (codes) used from the TOE framework using the initial raw data collected to test if the codes would be applicable to the raw data as well as the empirical codes. This process helped to check how credible the codes were before carrying out further interviews. This process was in a bid to place the research in a larger context.

The sample technique used is purposive sampling because the research emphasises on discovery and understanding of respondents' opinions and views instead of hypothesis testing (Schultze \& Avital, 2011). Snowball sampling was later used because the initial set of people interviewed identified other key informants who also took part in the interview. A total of 78 participants were drawn from Corporate Affairs Commission (CAC) however, 25 SMEs accepted to be interviewed. The criteria for selecting these persons is that each person must have engaged with MMT in the last one year, and have stayed in business for at least 3 years.

\subsection{Interviews and Analysis}

At first, 11 participants were interviewed using unstructured interview questions while 14 others were interviewed using semi-structured interviews questions. The reason for conducting unstructured interviews was to ascertain the nature of MMT in service SMEs in Nigeria and to develop the theoretical (technology-organisation-environment) and empirical code(s) that emerged in the process. This process helped to ascertain the credibility of the codes and to ensure that the subsequent raw data would be applicable to the codes before the initial validation (reliability test). The process was a guide that helped in designing the initial framework. The last 14 unstructured interviews helped in validating the framework developed at the initial stage. The unit of analysis was SME managers that 
have adopted MMT in their business. Table 1 below shows the participants and the type of services they render.

Before the whole exercise started, the researchers wrote a formal letter to the participants outing the aim of the research and issues of confidentiality. While some interviews lasted for 1 hour, others lasted for more than 1 hour. The interviews were recorded and all the raw data were later transcribed verbatim. Hybrid approach of thematic analysis was used to code the data into categories which allowed themes to emerge. Inter-rater reliability was conducted using percentage agreement (Boyatzis, 1998). This enabled a number of associates to rate the quotes. The reliability analysis revealed $79 \%$ and $88 \%$ per cent respectively which exceeded 70 per cent benchmark estimated by Miles and Huberman (1994).

\subsection{FINDINGS}

Tables 2 shows the themes, case evidence, cross case support and the number of cases coded which supported the hybrid approach of thematic analysis used in this study. Themes were emerged and clustered based on both theoretical (TOE) context and the empirical (value expectancy) context that unveiled factors shaping SMEs' adoption of MMTs.

\subsection{THE PROPOSED FRAMEWORK AND DISCUSSION}

The framework in Figure 2 was developed to identify the factors the shape MMT adoption which are discussed in the next section. However, it is important to note that the exploratory and explanatory nature of the framework and the factors emerged based on the respondents own views, opinions, theoretical codes and the empirical code.

\subsection{Technology}

\section{Operational Efficacy}

Operational efficacy is defined as the proficiency of the MMT in meeting the operations needs of the business. Although a number of small businesses in Nigeria are using the mobile app in their day to day business activities, most participants were of the view that MMT would be used if it demonstrates high efficient and performances. Table 4 reports that the themes from interviewee A5, A2 and A5 and cross-theme supports from interviewee A1, A3, A4, A7, A9, A11, A14, and A15 duly support these assertions. Similarly, a number of works have found that when an IT application is complex and difficult to use, it discourages adoption (Eze et al., 2018; Maduku et al. 2016; Eze at al 2019; Ramayah et al., 2016). The finding suggests that SMEs adopt MMT when the application demonstrates how efficient it is and the capacity to move the business to the next level.

\section{Adaptive Capability}

Adaptive capability defines the extent to which the new MMT integrates the organization's existing applications and business operations. Adaptive capability is a critical adoption factor; participant A3 and A13 with myriads of cross-theme supporters (see table 4) imply that managers try to identify and understand the opportunities of any new applications, and learn to avert and overcome failures by adopting those that are seamlessly compatible with the organization's arrangement. This finding is ideal because SMEs are often constrained by time and resources, and would not sue for costly venture of transferring data from old applications to new ones. Khoumbati et al. (2006a) and Fitzgerald and Kenny (2003) posit that the inability to integrate an infrastructure with the features of other existing ones may be a costly venture, any organizations must avoid at the onset. 
Table 1. Interview profile

\begin{tabular}{|c|c|c|c|}
\hline $\begin{array}{c}\text { Interview } \\
\text { Participants }\end{array}$ & Position & Company size & Type of Service \\
\hline $\mathrm{C} 1$ & Director & 65 & Security services \\
\hline $\begin{array}{l}\mathrm{C} 2 \\
\mathrm{C} 3 \\
\mathrm{C} 4\end{array}$ & $\begin{array}{l}\text { CEO } \\
\text { IT expert } \\
\text { IT expert }\end{array}$ & 105 & Digital marketing \\
\hline $\mathrm{C} 5$ & CEO & 25 & Consultancy \\
\hline C6 & Managing Director & 48 & Network provider \\
\hline $\begin{array}{l}\mathrm{C} 7 \\
\mathrm{C} 8\end{array}$ & $\begin{array}{l}\text { CEO } \\
\text { Manager }\end{array}$ & 110 & Consultancy \\
\hline C9 & Manager & 75 & Marketing \\
\hline $\mathrm{C} 10$ & CEO & 150 & Real Estate Management \\
\hline $\mathrm{C} 11$ & CEO & 20 & IT Vendor \\
\hline $\mathrm{C} 12$ & CEO & 52 & Consultancy \\
\hline $\mathrm{C} 13$ & $\mathrm{CEO}$ & 208 & IT developer \\
\hline $\mathrm{C} 14$ & CEO & 11 & Accounting services \\
\hline $\mathrm{C} 15$ & Director & 55 & IT consultancy \\
\hline $\mathrm{C} 16$ & Manager & 67 & IT consultancy \\
\hline $\mathrm{C} 17$ & CEO & 240 & IT Quality control \\
\hline $\mathrm{C} 18$ & CEO & 90 & IT consultancy \\
\hline $\mathrm{C} 19$ & Director & 11 & IT consultancy \\
\hline $\mathrm{C} 20$ & $\mathrm{CEO}$ & 21 & Consultancy \\
\hline $\mathrm{C} 21$ & $\mathrm{CEO}$ & 12 & Education \\
\hline $\mathrm{C} 22$ & CEO & 8 & Training \\
\hline $\mathrm{C} 23$ & Manger & 11 & Education \\
\hline $\mathrm{C} 24$ & $\mathrm{CEO}$ & 22 & Internet support services \\
\hline $\mathrm{C} 25$ & $\mathrm{CEO}$ & 33 & Advisory services \\
\hline $\mathrm{C} 26$ & CEO & 102 & IT Supports services \\
\hline
\end{tabular}

\section{Expandable Nature of the MMT}

The expandable nature of any mobile application determines how continually it accommodates new features. Observation shows that when an app is flexible in nature, it has the capacity to incorporate other features upon which business processes are carried out effectively. Participants A12 and A14 and their cross-case supporters (see table 4) revealed that when mobile application is expandable, it fast track business processes and reduce the cost of acquiring new application. From the analysis, small business are willing to use MMT if in future accommodates new application. In the same vein, Gholami et al., 2009) noted that the flexible and adaptable nature of any technology enhances its adoption and usage (Fitzgerald \& Kenny, 2003) 
Table 2. Factors that influence MMTs adoption, case evidence and cross-case supports

\begin{tabular}{|c|c|c|c|}
\hline $\begin{array}{l}\text { Mobile } \\
\text { marketing } \\
\text { adoption } \\
\text { factors }\end{array}$ & Case-evidence & Cross-case support & $\begin{array}{l}\text { No of } \\
\text { cases } \\
\text { coded }\end{array}$ \\
\hline $\begin{array}{l}\text { Code 1: } \\
\text { Technology: }\end{array}$ & \multirow{2}{*}{$\begin{array}{l}\text { "[--] the technology must demonstrate that it would be efficient and also render same services } \\
\text { big firms offer" (C5). } \\
\text { "We can only try the mobile app if it has the capacity to move the organization forward" (C2). } \\
\text { "[--] If the firm's operation can be efficient using the mobile app in such a way we can } \\
\text { compete with large organization, it will be tried" (C7) }\end{array}$} & & \\
\hline $\begin{array}{l}\text { Operational } \\
\text { efficacy }\end{array}$ & & $\begin{array}{l}\mathrm{C} 1, \mathrm{C} 3, \mathrm{C} 4, \mathrm{C} 8, \mathrm{C} 9, \mathrm{C} 11, \\
\mathrm{C} 14, \mathrm{C} 15\end{array}$ & 8 \\
\hline $\begin{array}{l}\text { Adaptive } \\
\text { Ability }\end{array}$ & $\begin{array}{l}\text { "Can the mobile app fit into the existing provisions of the firm's operations? If the app is } \\
\text { designed in a way it fits into our current operations, it will be embraced" (C3). } \\
\text { The app must be one that can be integrated into already existing application without much } \\
\text { external support? Can it really interface with others easily?" (C13). }\end{array}$ & $\begin{array}{l}\mathrm{C} 1, \mathrm{C} 2, \mathrm{C} 6, \mathrm{C} 10, \mathrm{C} 18, \mathrm{C} 14, \\
\mathrm{C} 16, \mathrm{C} 17, \mathrm{c} 20\end{array}$ & 9 \\
\hline \multirow[t]{2}{*}{$\begin{array}{l}\text { Expandable } \\
\text { nature of } \\
\text { MMT }\end{array}$} & $\begin{array}{l}\text { "The application must have the capacity to accommodate other application when the need } \\
\text { arises."(C12) } \\
\text { "The app must demonstrate its ability to house other prevailing applications that we use?" (C14). } \\
\text { "To be frank with you, we are considering apps that can help us integrate with we have already." } \\
\text { (C14) }\end{array}$ & $\begin{array}{l}\mathrm{C} 2, \mathrm{C} 3, \mathrm{C} 4, \mathrm{C} 13, \mathrm{C} 10, \mathrm{C} 18 \\
\mathrm{C} 19, \mathrm{C} 20, \mathrm{C} 21\end{array}$ & 8 \\
\hline & & & $\begin{array}{l}19 / 26 \\
(73 \%)\end{array}$ \\
\hline $\begin{array}{l}\text { Code2: } \\
\text { Organization }\end{array}$ & \multirow{2}{*}{$\begin{array}{l}\text { "Normally we come together and evaluate the application and its capacity before reaching a } \\
\text { decision" (C19). } \\
\text { I am not the only one in the company. I have to consider the initiatives of others. If you want us } \\
\text { to be competitive, others including those that are external to us must be involved" (C23). }\end{array}$} & & \\
\hline $\begin{array}{l}\text { Shared } \\
\text { Understanding }\end{array}$ & & $\begin{array}{l}\mathrm{C} 1, \mathrm{C} 5, \mathrm{C}, 7, \mathrm{C} 8, \mathrm{C} 15, \mathrm{C} 21, \\
\mathrm{C} 22, \mathrm{C} 22, \mathrm{C} 24, \mathrm{C} 26\end{array}$ & 10 \\
\hline \multirow[t]{2}{*}{$\begin{array}{l}\text { Extent of } \\
\text { business } \\
\text { Partnership }\end{array}$} & $\begin{array}{l}\text { "Sometimes it is good to be in a partnership, but most small businesses do not like it. } \\
\text { Collaboration even with rivalry is good when businesses in the same line come together to decide } \\
\text { what app would help them" (C12). } \\
\text { "Everybody in this business play a team role to ensure we get a technology that will aid } \\
\text { customers' satisfaction" (C15). }\end{array}$ & $\begin{array}{l}\mathrm{C} 1, \mathrm{C} 2, \mathrm{~A} 3, \mathrm{C} 4, \mathrm{C} 5, \mathrm{C} 13, \\
\mathrm{C} 16, \mathrm{C} 22, \mathrm{C} 23\end{array}$ & 8 \\
\hline & & & $\begin{array}{l}17 / 26 \\
(65 \%)\end{array}$ \\
\hline $\begin{array}{l}\text { Code 3: } \\
\text { Environment }\end{array}$ & \multirow{2}{*}{$\begin{array}{l}\text { "We like to be trained whenever the company acquires new technology. However, the time it } \\
\text { takes for the training matters to us. If the app required less time to master it, we go for it" (C11). } \\
\text { "Will it take us too much time to understand how the application works? It is highly unlikely that } \\
\text { we will adopt if the time required is much" (C2) } \\
\text { "If a new product is adopted, it often take a longer time to learn how to use it. (C9) }\end{array}$} & & \\
\hline $\begin{array}{l}\text { Degree of } \\
\text { Training }\end{array}$ & & $\begin{array}{l}\mathrm{C} 1, \mathrm{C} 4, \mathrm{C} 5, \mathrm{C} 9, \mathrm{C} 12, \mathrm{C} 13, \mathrm{C} 14, \mathrm{C} 17, \\
\mathrm{C} 18, \mathrm{C} 20\end{array}$ & 10 \\
\hline $\begin{array}{l}\text { Service } \\
\text { delivery }\end{array}$ & $\begin{array}{l}\text { "[--] How fast and secured is the application. Speed and security is overriding factor to us" (C15) } \\
\text { To what extent would the new application improve our operations and processes? "(C12) } \\
\text { The major reason we use this mobile technology is to improve our delivery and processes" (C12) }\end{array}$ & $\begin{array}{l}\mathrm{C} 2, \mathrm{C} 3, \mathrm{C} 7, \mathrm{C} 10, \mathrm{C} 11, \mathrm{C} 9, \\
\mathrm{C} 15, \mathrm{C} 16\end{array}$ & 8 \\
\hline \multirow[t]{2}{*}{$\begin{array}{l}\text { Customer } \\
\text { Fulfilment }\end{array}$} & $\begin{array}{l}\text { "Our clients are everything to us. We will not even attempt to adopt any app if the application } \\
\text { cannot demonstrate that it will satisfy our clients' needs" (C11). } \\
\text { "Mobile technology is considered by us as a means through which we can communicate and } \\
\text { transact with our clients. That is why we have one already...[--]" C12 }\end{array}$ & $\begin{array}{l}\mathrm{C} 1, \mathrm{C} 4, \mathrm{C} 5, \mathrm{C} 6, \mathrm{C} 7, \mathrm{C} 10, \\
\mathrm{C} 13, \mathrm{C} 14\end{array}$ & 8 \\
\hline & & & $\begin{array}{l}21 / 26 \\
(80 \%)\end{array}$ \\
\hline $\begin{array}{l}\text { Code } 4: \\
\text { Value } \\
\text { expectancy: }\end{array}$ & \multirow{2}{*}{$\begin{array}{l}\text { "We are relatively small and finance is still an issue to us. How cheap the application is will } \\
\text { determine if we go for it" }(\mathrm{C} 1) \\
\text { "[--] How would the application help us reduce the number of people that is working with us it } \\
\text { help us? "(C15) } \\
\text { "We have to take into consideration the cost and not the need it will satisfy alone" (C20) }\end{array}$} & & \\
\hline Cost & & $\begin{array}{l}\mathrm{C} 10, \mathrm{C} 2, \mathrm{C} 3, \mathrm{C} 5, \mathrm{C} 6, \mathrm{C} 7, \\
\mathrm{C} 9, \mathrm{C} 11, \mathrm{C} 13, \mathrm{C} 9, \mathrm{C} 16, \mathrm{C} 20, \\
\mathrm{C} 2, \mathrm{C} 3 .\end{array}$ & 11 \\
\hline \multirow[t]{2}{*}{$\begin{array}{l}\text { Business } \\
\text { Growth }\end{array}$} & $\begin{array}{l}\text { "If this application can help us grow our business that alone will be a motivation to use it" (C14) } \\
\text { "Can the app helps us increase our client base by } 30 \% \text { ? If the answer is yes, we will go for it" } \\
\text { (C5). } \\
\text { "If the mobile app is good for the growth of the business, I am sure the director will order for its } \\
\text { implementation " (C9) }\end{array}$ & $\begin{array}{l}\mathrm{C} 4, \mathrm{C} 6, \mathrm{C} 10, \mathrm{C} 15, \mathrm{C} 20, \\
\mathrm{C} 21, \mathrm{C} 23\end{array}$ & 5 \\
\hline & & & $\begin{array}{l}21 / 26 \\
(80 \%)\end{array}$ \\
\hline
\end{tabular}




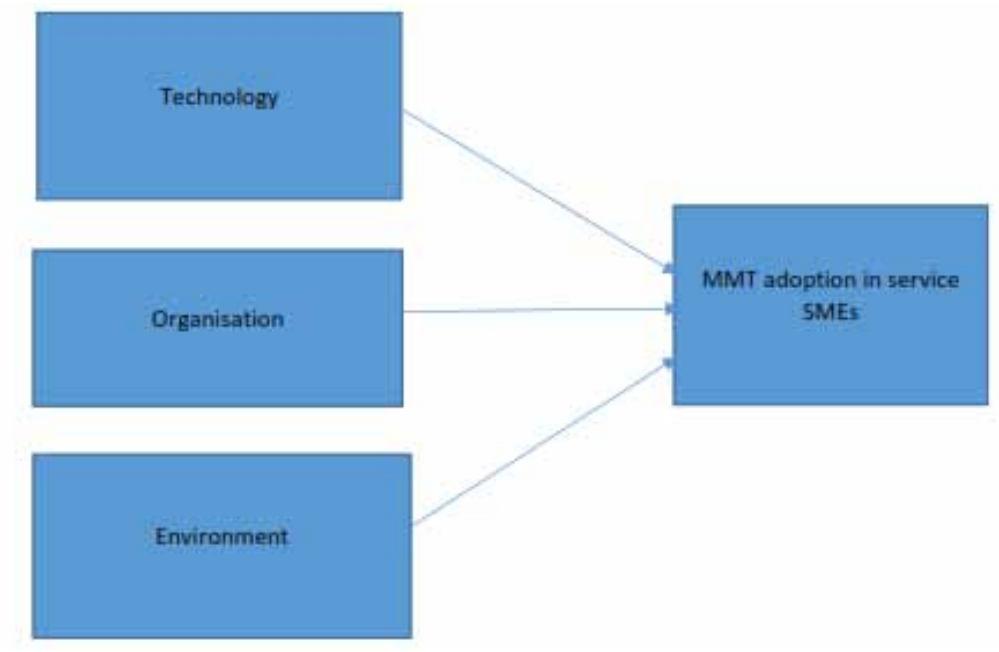

\subsection{Organization}

\section{Shared Understanding}

Shared understanding defines the cordiality of organization purpose and interest congruence of the employer, employees and external parties through open interaction. For informed decisions, MMTs must be understood by all interested parties, and the managers must acquire, share, process and disseminate business information that every person within or outside the firm understands. Table 4 shows that participants A19 and A23 with cross-case supporters affirm collective decision-making, given that the interest of all parties (within and outside the firm) is a competitive weapon. Scholars (Armstrong \& Sambamurthy, 1991; Reich \& Benbasat, 2000; Nelson \& Cooprider, 1996) noted that high level of support, interactions, as well as the setting in which the information is disseminated and assimilated add to its meaning and improve operational performance.

\section{Extent Of Business Partnership}

Extensive partnership is a virtue of competitive advantage in the modern age. Partnership defines the engagement of shared commitment and goals of various actors in coordinated manners to solve problems. Collaborative works when experts in specialized areas of IS share contents amongst themselves in order to ensure information flows in times of adoption. The perception is that most SMEs rarely partner together even when it is obvious that such helps to understand various stakeholders involved in the business. Most SME managers believe that when they collaborate, they expose their ideas and build for themselves competitive disadvantages with respect to the kind of mobile application they need. The managers (A12 and A15) and their cross-theme supporters (see table 4) realized the benefits of collaboration when they highlighted the need to integrate all stakeholders and their interest in the adoption process. (Reich \& Benbasat, 2000; Lip-Sam \& Hock-Eam, 2011; Polites \& Karahanna, 2012)

\subsection{Environment}

\section{Training Period}

Because of the regular emergence of new applications, old applications are often obsolete making the business clamor for the new application. This make training important for both the managers and workers in order to update themselves. Observation revealed that most employees and managers of 
SMEs go for training to update themselves on the most effective ways new applications can add value to the business. However, evidence shows the adoption of such applications will be most unlikely if such training consumes much time. Table 4 shows that this was echoed by A11, A2 and A9, and re-echoed across cases. This suggests that most SME managers do not have the time to go through the learning process. This is consistent with Rantapuska and Ihanainen, (2008) work.

\section{Service Delivery}

Service delivery is the extent to which the MMT is proficient and improve processes and profits. The cases (A15 and A12) and cross-theme supporters as reported in table 4 noted that MMT offered by consultants and vendors will be considered for adoption if it has the capacity to provide information that is reliable, extended service, and permits urgent client- endorsed inquiry. According to these participants, service delivery spans enhanced clients' responses to inquiries and problems, reduced labour cost, improved efficiency and productivity in terms of speed that builds competitive advantages (Xu et al., 2011). This suggests that if MMT improve business processes SMEs will show willingness to adopt it, and trigger mere prospects to adopters (Eze et al. 2018).

\section{Customer Fulfilment}

MMTs play critical roles in exchange process and reflect on customer fulfillment. Customer fulfilment represents the ability of the MMT to render services that would satisfy the needs and aspirations of potential and real customers. Moon (2003) posits that customers rely on MMT for important information about the products. Observation shows customers are more involved in adoption decisions that permit their business to flourish. Table 4 reported cases A14, A11 and A12 and the cross-case supporters, which affirm that adoption of technology applications is most guaranteed when they play pivotal roles in the perceived performance which is consistent with the work of Moon (2003).

\subsection{Value Expectancy}

\section{Cost}

Cost defines the acquisition consideration, as well as cost-effectiveness of real-time communications and integration when compared with other applications. By their nature, small businesses are known to be under-privileged, given their limited resources; and so, they aggressively seek technology applications that minimize cost of interactions and improve values and profit margin. Table 4 showed that cost factor was echoed by participants, A1, A5, A15, and A20, and supported by cross-themes; suggesting that cost shapes the value SMEs attach to MMT. Hence, adoption of any IT applications by small business owners depends on the cost-benefit analysis and the determination of the long-term strides (Pirich et al., 2001; Ramayah et al., 2016). If the cost associated with MMT is perceived high relative to its benefits; then, adoption will be highly unlikely.

\section{Business Growth}

IT applications improve productivity and assist SMEs to create new industries, and to carry out business activities outside the firm. Locke (2004) notes that improved performance associates with those SMEs that have specific growth objectives. However, business growth tied to the IT application includes staff strength, market share, turnover, sales volume, customer and market coverage, and return on investment. Observation revealed that SMEs study mobile applications, and often adopt those that guarantee high value for the business growth. According to Participants (A14, A5, A9 and A7) and their cross-theme supporters shows that that adoption of MMT is only a function of achieving business growth which is constant with previous studies (see Locke, 2004; Yousafzai \&Yani-de Soriano, 2012; Eze et al., 2018). 


\subsection{CONCLUSION AND IMPLICATIONS}

\subsection{Conclusion}

This study developed an extended contexts of T-O-E framework, and focused on 11 factors that critically influence MMT adoption. The factors are linked to technology, organization, environment and value expectancy. Factors that emerged from these categories that influence MMT adoption include: operational efficacy, adaptive ability, and expandable nature of the technology relate to technology. Shared understanding, extent of business partnership are organization related factors. Degree of training, service delivery, customer fulfilment are linked to environment factors while value expectancy factors include costs and business growth. The criticality of their strengths varies. For example, technology, organization, environment and value expectancy account for $73 \%, 65 \%$, $80 \%$, and $80 \%$ of the total supporting cases respectively

\subsection{Implications}

\section{Theoretical}

The extended T-O-E framework is a significant theoretical contribution, given that it provides more critical and context-specific insight into the frame of reference factors that shape the small business adoption of MMT. Further, the working definitions of the codes and the factors serve as analytical tools for scholars to robustly comprehend and describe factors that influence MMT adoption. Macredie and Mijinyawa, (2011) posit that most studies are besieged with the inability to effectively defined theoretical concepts in relation to the analysis and confirmation of the factors. However, the additional codes and the related factors outside the original contexts of T-O-E frameworks are clearly defined to guarantee the extension and enrichment of the existing body of knowledge/literature on adoption. Therefore, the identified constructs and factors could guide the development of hypotheses which could help validate the link between the categories and the factors using confirmatory techniques.

\section{Practical}

This study's proposed framework serves a frame of reference of factors and their criticalities, and provides uncommon insights into MMT adoption by service SMEs. This framework provides practitioners with justification for informed courses of action in the context of MMT adoption. Further, managers could use the study's argument, as well as the empirical insight to create consciousness on the benefits and problems of using of MMTs among the SMEs. For instance, in taking decisions, managers must recognize that environmental and valued expectancy context is most critical, followed by technology context, organization context and context.

\subsection{Research Limitations}

This study has some limitations because of the approach adopted. The study is qualitative in nature, and the method used in relation to the design, rigour, data collection and analysis may result to unexpected participants and research bias with regards to data analysis. This may lead to inadequate understanding of the insights into the factors shaping MMT adoption. Therefore other techniques and approaches ranging from mix-method, case study and sentimental analysis may be used to validate the finding further and incorporate other factors which may have not appeared in this study. Also, one of the limitations of qualitative research is the issue of theoretical generalizability of the framework. Future studies should be conducted in order to generalize the formwork. This entails using a wider range of population and sample size and using techniques such as confirmatory statistical techniques to test, and validate the framework across a large population of MMT adopters in Nigeria. 


\section{REFERENCES}

Adams, D., Nelson, R., \& Todd, P. (1992). Perceived usefulness, ease of use, and usage of information technology: A replication. Management Information Systems Quarterly, 16(2), 227-247. doi:10.2307/249577

Ajzen, I., \& Fishbein, M. (Eds.). (1980). Understanding attitudes and predicting social behavior. Prentice-Hall.

Alshamaila, Y., Papagiannidis, S., \& Li, F. (2013). Cloud computing adoption by SMEs in the north east of England: A multi-perspective framework. Journal of Enterprise Information Management, 26(3), $250-275$. doi:10.1108/17410391311325225

Amirkhanpour, M., Vrontis, D., \& Thrassou, A. (2014). Mobile marketing: A contemporary Strategic perspective. Academic Press.

Andries, P., \& Debackere, K. (2006). Adaptation in new technology-based ventures: Insights at the company level. International Journal of Management Reviews, 8(2), 91-112. doi:10.1111/j.1468-2370.2006.00122.x

Armstrong, C., \& Sambamurthy, V. (1991). Technology Assimilation in Firms: The influence of senior leadership and IT infrastructures. Information Systems Research, 17(1), 99-120.

Awa, H. (2018). Some antecedent factors that shape actors' adoption of enterprise systems. Enterprise Information Systems. Advance online publication. doi:10.1080/17517575.2018.1466368

Awa, H., \& Ukoha, O. (2016). A model of adoption determinants of ERP within T-O-E. Journal of Information Technology \& People, 24(4), 901-930. doi:10.1108/ITP-03-2015-0068

Awa, H., Ukoha, O., \& Emecheta, B. (2015). Integrating TAM, TPB, and TOE frameworks and expanding their Characteristic Constructs for E-commerce Adoption by SMEs. Journal of Science and Technology Policy Management, 1(2), 76-94. doi:10.1108/JSTPM-04-2014-0012

Awa, H., Ukoha, O., \& Igwe, S. (2017a). Revisiting technology-organization-environment (T-O-E) theory for enriched applicability. The Bottom Line (New York, N.Y.), 30(01), 2-22. doi:10.1108/BL-12-2016-0044

Baker, J. (2012). The technology-organization-environment framework. Information Systems Theory. Springer.

Balasubramanian, S., Peterson, R., \& Jarvenpaa, S. (2002). Exploring the Implications of m-commerce for markets and marketing. Journal of the Academy of Marketing Science, 30(4), 348-361. doi:10.1177/009207002236910

Boyatzis, R. (1998). Transforming qualitative information: Thematic analysis and code development. Sage Publication Ltd.

Charoensukmongkol, P., \& Sasatanun, P. (2017). Social media use for CRM and business performance satisfaction: The moderating roles of social skills and social media sales intensity. Asia Pacific Management Review, 22(1), 25-34. doi:10.1016/j.apmrv.2016.10.005

Davis, F. (1989). Perceived usefulness, perceived ease of use and acceptance of information technology. Management Information Systems Quarterly, 3(3), 319-340. doi:10.2307/249008

Earl, M., \& Feeny, D. (2012). How to be a CEO for the information age. Sloan Management Review, 14(2), 11-23.

Ekakitie-Emonena, S., \& Odanibeh, J. (2016). Mobile Marketing in a Digital Age: Application, Challenges \& Opportunities. British Journal of Economics. Management \& Trade, 11(1), 1-13.

Eze, S., Awa, H., Okoye, J., Emecheta, B., \& Anazodo, R. (2013). Determinant factors of Information communication technology (ICT) adoption by government-owned universities in Nigeria: A qualitative approach. Journal of Enterprise Information Management, 26(4), 427-443. doi:10.1108/JEIM-05-2013-0024

Eze, S., \& Chinedu-Eze, C. (2018). Examining information and communication technology (ICT) adoption in SMEs: A dynamic capabilities approach. Journal of Enterprise Information Management, 31(2), $338-356$. doi:10.1108/JEIM-12-2014-0125

Eze, S., Duan, Y., \& Chen, H. (2012). Factors Affecting Emerging ICT Adoption in SMEs: An Actor Network Theory Analysis. International Conference on E-business Technology \& Strategy (ICETS), Tanjin, China. 
Eze, S., Duan, Y., \& Chin, H. (2014). Examining Emerging ICT's Adoption in SMEs from a dynamic Process Approach. Information Technology \& People, 27(1), 63-82. doi:10.1108/ITP-03-2013-0044

Eze, S., Olatunji, S., Chinedu-Eze, V., \& Bello, A. (2018). Key success factors influencing SME managers' information behaviour on emerging ICT (EICT) adoption decision-making in UK SMEs. The Bottom Line (New York, N.Y.), 31(3/4), 250-275. doi:10.1108/BL-02-2018-0008

Eze, S.C., Chinedu-Eze, V.C., \& Bello, A.O. (2020). Some antecedent factors that shape SMEs adoption of social media marketing applications: a hybrid approach. Journal of Science and Technology Policy Management. 10.1108/JSTPM-06-2019-0063

Eze, S. C., Chinedu-Eze, V. C., Bello, A. O., Inegbedion, H., Nwanji, T., \& Asamu, F. (2019). Mobile marketing technology adoption in service SMEs: A multi-perspective framework. Journal of Science and Technology Policy Management, 10(3), 569-596. doi:10.1108/JSTPM-11-2018-0105

Fitzgerald, B., \& Kenny, T. (2003). Open source software in the trenches: Lessons from a large-scale implementation. In Proceeding of the 24th International Conference on Information Systems. The Association for Information Systems.

Friedman, T. (2005). The World is Flat: A Brief History of $21^{\text {st }}$ Century. Farrar, Straus \& Giroux.

Gholami, B., Kaviani, F., \& Zabihi, E. (2009). Web 2.0, a boost in IT infrastructure flexibility and team collaboration. In Second International conference on computer and electrical engineering. IEEE Computer Society.

Gilmore, A., \& Carson, D. (2007). Teaching and research in small business enterprise marketing: A critique and some alternatives. In Innovative Methodologies in Enterprise Research. Cheltenham, UK: Edward Elgar. doi:10.4337/9781847204271.00009

Gupta, P., Seetharaman, A., \& Raj, J. (2013). The usage and adoption of cloud computing by small and medium businesses. International Journal of Information Management, 33(5), 861-874. doi:10.1016/j. ijinfomgt.2013.07.001

Gutierrez, A., Boukrami, E., \& Lumsden, R. (2015). Technological, organisational and environmental factors influencing managers' decision to adopt cloud computing in the UK. Journal of Enterprise Information Management, 28(6), 788-807. doi:10.1108/JEIM-01-2015-0001

Harvie, H. (2010). East Asian production networks: The role and contribution of SMEs. International. Journal of Business and Development Studies, 2(1), 27-62.

Henderson, B., Kobelsky, K., Richardson, V., \& Smith, R. (2010). The relevance of information technology expenditure. Journal of Information Systems, 24(2), 39-77. doi:10.2308/jis.2010.24.2.39

Honarzade, M., Mahboubeh Mahmoudinia, M., \& Anari, M. S. (2018). Identifying and Ranking Influencing Factors in Using RFID Technology in Tourism Industry via the Use of Structural. International Journal of Information Systems in the Service Sector, 10(4), 1-20. doi:10.4018/IJISSS.2018100101

Ihua, B. (2009). SMEs key failure-factors: A comparison between the United Kingdom and Nigeria. Journal of Social Sciences, 18(3), 199-207. doi:10.1080/09718923.2009.11892682

Inegbedion, H., Inegbedion, E. E., Osifo, S. J., Eze, S. C., Ayeni, A., \& Akintimehin, O. (2019). Exposure to and usage of e-banking channels: Implications for bank customers' awareness and attitude to e-banking in Nigeria. Journal of Science and Technology Policy Management, 11(2), 133-148. doi:10.1108/JSTPM-02-2019-0024

Inegbedion, H., \& Obadiaru, E. (2018). Modelling brand loyalty in the Nigerian telecommunications industry. Journal of Strategic Marketing. Advance online publication. doi:10.1080/0965254X.2018.1462842

Khoumbati, K., Themistocleous, M., \& Irani, Z. (2006a). Evaluating the adoption of enterprise application integration in health- care organisation. Journal of Management Information Systems, 22(4), 69-108. doi:10.2753/ MIS0742-1222220404

Kim, G., Park, S., \& Oh, J. (2008). An examination of factors influencing consumer adoption of short message service (SMS). Psychology and Marketing, 25(8), 769-786. doi:10.1002/mar.20238 
Kuan, K., \& Chau, P. (2001). A perception-based model for EDI adoption in small businesses using a technology-organization-environment framework. Information \& Management, 38(8), 507-521. doi:10.1016/ S0378-7206(01)00073-8

Lamarre, A., Galarneau, S., \& Harold-Boeck, H. (2012). Mobile marketing and consumer behaviour: Current research trend. International Journal of Latest Trends in Computing, 3(1), 1-9.

Leppäniemi, M., \& Karjaluoto, H. (2008). Mobile marketing: From marketing strategy to mobile marketing campaign implementation. International Journal of Mobile Marketing, 3(1), 50-61.

Lip-Sam, T., \& Hock-Eam, L. (2011). Estimating the determinants of B2Be-commerce adoption among small \& medium enterprises. International Journal of Business and Society, 12(1), 15-30.

Locke, S. (2004). ICT adoption and SME growth in New Zealand. The Journal of American Academy of Business, Cambridge, 3(13), 93-102.

Ma, J., Suntornpithug, N., \& Karaatli, G. (2009). Mobile advertising? Does it work for everyone? International Journal of Mobile Marketing, 4(2), 28-35.

Macredie, R., \& Mijinyawa, K. (2011). A theory -grounded framework of open source software adoption in SMEs. European Journal of Information Systems, 20(2), 237-250. doi:10.1057/ejis.2010.60

Madukua, D., Mpinganjirab, M., \& Duhca, H. (2016). Understanding mobile marketing adoption intention by South African SMEs: A multi-perspective framework. International Journal of Information Management, 36(5), 711-723. doi:10.1016/j.ijinfomgt.2016.04.018

Martin, L., \& Matlay, H. (2001). Blanket approaches to promoting ICT in small firms: Some lessions from the IDT ladder adoption model in the UK. Internet Research. Electronic Networking Applications and Policy, 11(5), 399-410. doi:10.1108/EUM0000000006118

Mehrtens, J., Cragg, P., \& Mills, A. (2001). A model of Internet adoption by SMEs. Information \& Management, 39(3), 165-176. doi:10.1016/S0378-7206(01)00086-6

Miles, M., \& Huberman, A. (1994). Qualitative data analysis: An expanded sourcebook. Sage Publication Ltd.

Moon, Y. (2003). Don't blame the computer when self -disclosure moderates the self-serving bias. Journal of Consumer Psychology, 13(1/2), 125-137.

National Bureau of Statistics. (2015). Nigerian Gross Domestic Product report, Quarter three. Author.

Nelson, K., \& Cooprider, J. (1996). The contribution of shared knowledge to IS Group performance. Management Information Systems Quarterly, 20(4), 409-429. doi:10.2307/249562

Nguyen, T., Newby, M., \& Macaulay, M. (2015). Information Technology Adoption in Small Business: Confirmation of a Proposed Framework. Journal of Small Business Management, 53(1), 207-227. doi:10.1111/ jsbm. 12058

Ojeme, S., \& Onuba, I. (2010). CBN sets up 200bn SME credit guarantee scheme. The Punch, 19(April), 17.

Oliveira, T., \& Martins, M. (2011). Literature review of information technology adoption models at firm level. The Electronic Journal Information Systems Evaluation, 14, 110-121.

Ongori, H., \& Migiro, S. (2010). Information and communication technology adoption: Literature review. Journal of Chinese Entrepreneurship, 2(1), 93-100. doi:10.1108/17561391011019041

Orlikowski, W. (1993). Case Tools as Organizational Change: Investigating Incremental and Radical Changes in Systems Development. Management Information Systems Quarterly, 17(3), 309-341. doi:10.2307/249774

Park, J. \& SuJin,Y. (2006). The moderating role of consumer trust and experiences: Value driven usage of mobile technology. International Journal of Mobile Marketing, 1(2), 24-32.

Pavlou, P., \& Fygenson, M. (2006). Understanding and predicting electronic commerce adoption: An extension of the Theory of Planned Behaviour. Management Information Systems Quarterly, 30(1), $115-143$. doi:10.2307/25148720 
Pirich, A., Knuckey, S., \& Campbell, J. (2001). An Interface between entrepreneurship and innovation:New Zealand SMEs perspective. In DRUID Nelson and Winter Conference. Aalborg University.

Polites, G., \& Karahanna, E. (2012). Shackled to the status quo: The inhibiting effects of incumbent system habit, switching cost, and inertia on new system acceptance. Management Information Systems Quarterly, 36(1), 21-42. doi:10.2307/41410404

Porter, M., \& Millar, V. (1985). How information gives you competitive advantage. Harvard Business Review, 63(4), 149-160.

Premkumar, G. (2003). A meta-analysis of research on information technology implementation in small business. Journal of Organizational Computing, 13(2), 91-121. doi:10.1207/S15327744JOCE1302_2

Ramayah, T., Ling, N., Taghizadeh, S., \& Rahman, S. (2016). Factors influencing SMEs website continuance intention in Malaysia. Telematics and Informatics, 33(1), 150-164. doi:10.1016/j.tele.2015.06.007

Ramdani, B., \& Kawalek, P. (2008). Exploring SMEs' adoption of broadband in the Northwest of England. In Handbook of Research on Global Diffusion of Broadband Data Transmission (pp. 504-523). IGI Global. doi:10.4018/978-1-59904-851-2.ch032

Rantapuska, T., \& Ihanainen, O. (2008). Knowledge use in ICT investment decision making of SMEs. Journal of Enterprise Information Management, 21(6), 585-596. doi:10.1108/17410390810911195

Reich, B., \& Benbasat, I. (2000). Factors that influence the social dimension of alignment between business and information technology objectives. Management Information Systems Quarterly, 24(1), 81-111. doi: $10.2307 / 3250980$

Rogers, E. (1995). Diffusion of innovation. Free Press.

Saeidpour, P., Otarkhani, A., \& Shokouhyar, S. (2018). Predicting Customers' Churn Using Data Mining Technique and its Effect on the Development of Marketing Applications in Value-Added Services in Telecom Industry. International Journal of Information Systems in the Service Sector, 10(4), 59-72. 10.4018/IJISSS.2018100104

Schultze, U., \& Avital, M. (2011). Designing Interviews to Generate Rich Data for Information Systems Research. Information and Organization, 21(1), 1-16. doi:10.1016/j.infoandorg.2010.11.001

Shankar, V., \& Balasubramanian, S. (2009). Mobile marketing: A synthesis and prognosis. Journal of Interactive Marketing, 23(2), 118-129. doi:10.1016/j.intmar.2009.02.002

Shankar, V., Venkatesh, A., Hofacker, C., \& Naik, P. (2010). Mobile marketing in the retailing environment:Current insight and future research avenue. Journal of Interactive Marketing, 24(2), 111-120. doi:10.1016/j. intmar.2010.02.006

Small and Medium Sized Development Agency of Nigeria (SMEDAN). (2005). SME Success Digest, 3(1), 1-6.

Strom, R., Vendel, M., \& Bredican, J. (2014). Mobile marketing: A literature review on its value for consumers and retailers. Journal of Retailing and Consumer Services, 21(6), 1001-1012. doi:10.1016/j.jretconser.2013.12.003

Tilley, F., \& Tonge, J. (2003). Introduction. In Advantages in SME: Organising for Innovation and Change. John Wiley and Sons Ltd.

To, M. L., \& Ngai, E. W. T. (2006). Predicting the organizational adoption of B2C e-commerce: An empirical study. Industrial Management \& Data Systems, 106(8), 1133-1147. doi:10.1108/02635570610710791

Tornatzky, L., \& Fleischer, M. (1990). The Processes of Technological Innovation. Lexington Books.

Watjatrakul, B. (2018). Determinants and Effects of Mobile Service Customization: An Empirical Study of A2P SMS Adoption. International Journal of Information Systems in the Service Sector, 10(4), 73-8710. doi:10.4018/ IJISSS.2018100105

Williams, M., Dwivedi, Y. K., Lal, B., \& Schwarz, A. (2009). Contemporary trends and issues in IT adoption and diffusion research. Journal of Information Technology, 24(1), 241-10. doi:10.1057/jit.2008.30

Xu, J., Benbasat, I., \& Cenfetelli, R. (2011). The effects of service and consumer product knowledge on online customer loyalty. Journal of the Association for Information Systems, 12(11), 741-766. doi:10.17705/1jais.00279 
Xu, M., Rohatgi, R., \& Duan, Y. (2007). E business adoption in SMEs: Some preliminary findings from electronic component industry. International Journal of E-Business Research, 3(1), 74-90. doi:10.4018/jebr.2007010105

Yousafzai, S., \& Yani-De-Soriano, M. (2012). Understanding customer-specific factors underpinning internet banking adoption. International Journal of Bank Marketing, 30(1), 60-81. doi:10.1108/02652321211195703

Vera Chinwendu Chinedu-Eze is presently a lecturer in the Department of Agric-Business, Michael Okpara University of Agriculture, Umudike, Umuahia, Nigeria. Her research interests include e-learning, agri-business, SMEs, gender issues, human resources management.

Hart O. Awa has L-8298-2019 as a Web of Science (WOS) ResearcherID, powered by Publons of Wiley. He is a professor of Marketing, and a research point-man of the Department of Marketing and Faculty of Management Sciences, University of Port Harcourt, Nigeria. Hart writes and reviews for top-indexed and WOS journals, many of which are housed in Emerald, Taylor \& Francis, Elsevier, Wiley, and Sage. He is a member of Emerald Literati Network, UK and Informing Science, US, and a Fellow of Word Business Institute (WBI), Australia. 